\title{
3 Roots: Understanding Belonging
}

I must confess that I took the idea of labelling this chapter 'roots' and the following one 'routes' from Johannes von Moltke (2005), who did so as well in his book No Place Like Home. He used these terms to describe where the idea of the Heimatfilm, a German movie genre, originated from (his 'roots') and which development it took (his 'routes'). I rather think of 'roots' and 'routes' in the geographic sense of considering how people incorporate both places and mobility into their lifeworlds. But this idea is also not mine; I found it later on in Duyvendak's interesting book The Politics of Home (2011), in which he also distinguishes between 'roots' and 'routes' to describe the two main reference dimensions of home-making practices of 'chronically mobile' people. I think that this pair of words describes quite well the changing relations to places that people develop in a mobile world. I will start with a reflection on 'roots'; this chapter will deal with the role of places in the everyday life of people. Whereas we have heard in the previous chapter how particularly creative knowledge workers use 'place(s)' in their work life, there is also a wider understanding of how we relate or belong to places. I will try to illustrate this by using the concepts of (1) home/Heimat, of (2) place-based identity, of (3) dwelling/Wohnen, and finally of (4) psycho-social sedentariness. Furthermore, I will reflect the changing nature of place relations by presenting two current approaches by Duyvendak (2011) and Dienel (2009), which both look for an understanding of place relations in a mobile world.

\subsection{The Concept of Heimat}

One remark in advance: the German word Heimat is very difficult to translate into other languages, as the word itself is deeply rooted in German history. Applegate (1990), a US American historian, studied how Germans first grounded their Heimat concepts in their own cities and regions (the local scale); while later the government sought to artificially construct Heimat on the national scale. She remarks (1990: 4), 'Heimat carries a burden of reference and implication that is not adequately conveyed by the translation homeland or hometown.' Other authors also agree on the difficulty of this translation. For example, von Moltke (2005) faced the same problem, to which he has offered a pragmatic solution: he translates Heimat to 'home' in English, using 'homeland' when it comes precisely to the national scale of Heimat, and 'hometown' when he refers to the local scale of Heimat. I will also be pragmatic here, and use both terms Heimat and 'home' more or less equivalently, even though I am aware of the difficulties of doing so.

The notion of Heimat, or home, is a central concept in the migration literature. Migration research that focuses on return migration after periods abroad as well as the research that deals with expelled 'diasporas', uses this concept to explore how people are 'rooted' and how they refer to certain localities. In a study on returning 
migrants, Scheffel (2012) provided an interesting review of how the concept of Heimat has developed until now. According to Scheffel, the German word Heimat showed up in the 17th century, when it referred to one's own house or farm. It described the belonging of a person to a place. With time, the geographic connotation extended to wider areas and was upscaled. Heimat rapidly included the whole village and the local community that existed there. When industrialization caused a massive migration from rural places to the growing cities, many people became even more aware of Heimat. Narratives and discourse from that time show that those who lived in industrialised cities suffered from homesickness for the village and the countryside from whence they came. The early urban industrial society was characterised by Heimat, which was distant and lost to a certain extent. Heimat became a romanticised image of the countryside (Scheffel, 2012). Applegate also notes (1990: 9): 'The Heimat of numerous novels and poems about the countryside and village life was an idyll of local communities, close family harmony, and a domesticated, friendly nature [which] stood in opposition to the city.'

In the period of nation building during the 19th and 20th century the notion of Heimat became an instrument of national governments. In the 1820s Heimat was transferred to the national scale. As Applegate describes (1990: 8), 'The [...] administrators were substituting a new principle of state citizenship for the old practice of community control over who belonged and who did not. That so familiar and innocuous a term as Heimatrecht should have embodied this principle reveals an important moment, not just in the confrontation between bureaucrats and hometownsmen, but in the discussion within the progressive bureaucracy on the role of localities in a greater state.' The homeland became the central issue. This moment included a duality between the local and national scale, both of which should be part of the Heimat. The suggestion at that time was ' $a$ basic affinity between the new, abstract political units and one's home, thus endowing an entity like Germany with the emotional accessibility of a world known to one's own five senses. [...] Heimat was both the beloved local places and the beloved nation' (Applegate, 1990: 10/11). In her book, Applegate analysed how different scales were incorporated by the national scale. She mentions that through media and political discourse the nation as scale of Heimat had 'settled into people's minds', and how the nation then embraced 'their smaller worlds [regional and local Heimat]; Germanness could encompass their diversity' (Applegate, 1990: 13). This observation shows that 'being rooted' in space does not only relate to a place, a local scale. The higher scales often articulate themselves in the local one. I think this quote from Applegate also fits the rhetoric of the European Union and its official motto 'United in Diversity', which indicates the next step in the upscaling process. Yet, the nation state always remained an abstract construct that was difficult to describe and to be identified with. Poets of different periods in German history used the local scale as something what could be experienced and grasped, and what was then constructed as the immediate notch of a nation and national community. 
As a result of the World Wars and fascist regimes in Europe, scientists were reluctant to use the notion of Heimat throughout the 1960s and 1970s, and many are still reluctant today. However, with rising mobility as well as global and European integration, Heimat has once again become a central concept in migration studies (cf. Scheffel, 2012). For many migrants, the feeling of attachment to a specific place has become an issue again. Von Moltke (2005: 7) remarks: '[...] more recently it has come to serve as a trope for identity politics in an increasingly multicultural society.' This new notion of Heimat implies that people in general, and migrants in particular, construct Heimat actively and self-responsibly. Heimat can no longer be controlled by national governments, because people decide on their own where they feel attachments in a global world.

The problem with the term Heimat is that it has been used for many decades in popular as well as academic language, but there is no clear conceptualisation. It is used differently in different periods (cf. Applegate, 1990). Anton Kaes has concluded that the only possible way of bringing together all of these different connotations is to speak of 'everything that is not distant and foreign' (Kaes; cited in von Moltke, 2005: 8). And von Moltke adds (2005: 8): 'The longevity of Heimat as a keyword has much to do with this semantic flexibility. One of the defining characteristics of the word may be its adaptability to different contexts. On the other hand, such flexibility poses serious problems for any attempt to pin down its meaning.'

The Italian philosopher Giuseppe Duso (2004: $21^{11}$ ) tries to define it as follows: 'The notion of Heimat refers to a physical, cultural and mental dimension, which gives us the feeling that we are at home in the world around us. We recognise our identity, perceive it as an acknowledged one, and we feel rooted in the world and in a set of relationships. This rootedness makes sure that we are part of an ethic context, which appears as a shared one, and which at the same time is able to found individual action in its very subjectivity.'

Scheffel tries to pin it down even more precisely by explaining that Heimat is based on the imagination, values and norms that a person internalises throughout the socialisation process. Six dimensions are important here (2012: 78):

- First, the spatial dimension describes the physical extension, the actual territory that is part of the individual Heimat.

- Second, the cultural dimension includes values, language, symbols and habits that are related to the place and shared with others who also stem from that

11 Translated by the author from the German text: 'Der Ausdruck Heimat verweist auf eine physische, kulturelle und geistige Dimension, die uns das Gefühl gibt, daß wir in der uns umgebenden Welt zu Hause sind. Wir erkennen unsere Identität, erfahren sie als eine anerkannte und fühlen uns in der Welt und in einer Reihe von Beziehungen verwurzelt. Diese Verwurzelung sorgt dafür, daß wir Teil eines ethischen Zusammenhangs sind, der als gemeinsamer erscheint und zugleich imstande ist, die individuellen Handlungen in ihrer Subjektivität zu fundieren. 
place. The cultural dimension might be used to distinguish one's own Heimat from other places with a different culture.

- Third, Heimat has a temporal dimension. Only with the passing of time and with experiences that are related to a certain place, this place also can become a Heimat. A person has to live in the place in order to experience it, and with growing experience, a feeling of attachment and belonging evolves. A certain history can be told about that place of Heimat.

- The fourth dimension is the social one. This means that not only the atomic and individual life in a place constitutes Heimat, but also the fact that a person shares their feelings with others in that place. Communication is a central issue in defining Heimat. People exchange their experiences and thus identify what Heimat means and what it is. Heimat is an inter-subjective concept. This includes the observation that Heimat often refers to a social space in which there is a minimum density of social relations and interaction, and in which people mutually understand each other without intercultural translation.

- Fifth, there is also a psychological dimension to Heimat. Based on temporal and social dimensions people develop an emotional affiliation to a certain place or to a region which they consider Heimat. The emotions are mostly positive, e.g. people feel at ease with places, or they feel they can be themselves without having to play artificial roles. This includes a strong relation to place-based identification patterns (which will actually be explained in section 3.2). The emotional aspect also becomes evident when people are far from their Heimat and they start to feel homesick.

- Finally, there is an economic and legal dimension that makes up Heimat. The place itself must allow a person a free life in terms of labour market access and the guarantee of economic survival.

We can see that the concept of Heimat is composed of various intertwining dimensions. By acknowledging these dimensions, we can study how people develop an attachment to a place and how they develop 'roots'.

\subsubsection{There's no Place like Home}

The phrase 'There's no place like home', which comes from the movie The Wizard of $\mathrm{Oz}$, was used by Johannes von Moltke (2005) as an inspiration for the title of his book on imaginations of Heimat in German cinema. But where is this place called 'home' in geographical terms? The problem with Heimat is that it is often unclear to which geographical place, space or scale it might refer. Von Moltke examines this problem with reference to Applegate and Confino. Applegate, he says, breaks down Heimat as a mediator between the local and the national scale, while Confino describes the local as being a metaphor for the national. Von Moltke explains that Heimat primarily describes a relation between people and space. Common suggestions here are the 
place where one spent their childhood or a place one has chosen as a second home during the course of one's life (von Moltke, 2005). Von Moltke (2005: 10) also cites a dictionary from the late 1950s in which Heimat was defined as the territory in which the 'totality of life' is located, and which can be distinguished against other foreign places and areas. This dictionary's definition also includes a connotation of physical abilities of the human being for it says that 'the world of Heimat is necessarily small, for only then it can be experienced completely and be open to that complete familiarity in which humans can take comfort in being at home' (cited in von Moltke, 2005: 10). This idea of the experience of the 'totality of life' also shows up in other words as the 'personally inhabited space'. Von Moltke underlines that Heimat is a part of a wider space that can be experienced in an individual and immediate way. He resumes (2005: 11): '[...] We think of it as place, as limited terrain that affords its inhabitants respite and protection from incursions originating in the more intangible and abstract spaces beyond its boundaries.'

Yet, von Moltke also makes global mobility an issue in his discussion on the concept of Heimat. Contrary to Scheffel, who uses the rising mobility as an argument to say that Heimat is becoming more important to 're-root' the people, von Moltke implies in his post-modern notion of Heimat that there is an interplay between physically present and distant elements on the local level. This idea was originally developed by Anthony Giddens, who said: 'Place becomes increasingly phantasmagoric: that is to say, locales are thoroughly penetrated by and shaped in terms of social influences quite distant from them' (Giddens; cited in von Moltke, 2005: 12/13). Von Moltke thus argues that Heimat should not be equated to one confined place. Heimat must be understood as a geographic relation between different scales (e.g. the local and the global) or between distant places. If one stuck to the static and pre-modern version of Heimat as one confined place, one would only reproduce the 'invented tradition', this nostalgic hindsight that was supposed to help people orientate in modern times, as von Moltke argues (2005: 14). Yet, there were and are many more connotations to Heimat. There were the legal aspects related to modern national citizenship; there were the connotations related to modern urban environments and technological progress; and therefore there was always a linking function between modernity and tradition.

The standpoint of Pasonati (2004), after having hosted a scientific conference about regional identities in the Austrian and Italian Alps, is similar. Pasonati generally observes that the national scale references of Heimat lose ground to the regional scale within Europe. At the same time, the European scale is not yet referred to as Heimat by most of the Europeans. This whole process of changing geographical references includes a de-territorialisation and disorientation. People are looking for new geographical anchor points. Pasonati concludes (2004: 14'12): 'Nowadays Heimat can

12 Translated by the author from the German text: 'Heimat kann heute nicht mehr bedeuten, an einem lauschigen Plätzchen der Provinz und in ländlicher Zurückgezogenheit seinen Traum vom Glück verwirk- 
no longer mean the wish to make one's own idea of happiness a reality in a cosy place in the country and in rural privacy. Rather it is about looking for the new meanings of the word within the context of the natural and general longing for security or any type of anchor place.'

Given the current dynamics in global and European mobility, Duyvendank thinks of home as a 'multi-faceted and multi-scalar' phenomenon (2011: 4). Within this multiscalarity, different scales have different meanings that are interrelated and sum up to a coherent pattern for the individual person. According to Duyvendank, the nation as well as the community on the local scale and finally the house and household are the main scales of reference for feeling at home. Duyvendank also thinks that the national scale is somehow losing importance, and the local community might become more important than it has been so far. Equally, Gustafson (2001: 680) writes: 'Place attachment may be directed toward residence, neighbourhood, city, region, or country (and indeed toward several places of different spatial scale).' Thus, we can see that it is not an easy issue to link the notion of Heimat to a specific geographical frame of reference. Different scales are intertwined, and also multiple references on the same scale might exist in parallel within a person's idea of Heimat - e.g. two or more cities, or two or more regions.

\subsubsection{Home is Where your Heart is}

This famous phrase makes clear that there is also an emotional aspect to home or Heimat. For example, it shows up as a metaphor in Kearns \& Smith's (1994) quote on homelessness: 'Someone might be adequately housed but spatially removed from their acutely felt sense of home (i.e. some other place of greater felt meaning or value)' (Kearns \& Smith, 1994: 420; cited in Cloke et al., 2002: 13). Cloke et al.'s (2002) subject is homelessness as well. In order to deal with it, they start from the notion of home and then link home and homelessness as mutually influencing aspects. For them, the 'metaphorical homelessness' as described by Kearns \& Smith (1994) includes that the idea of having a home is far more complex than only possessing of access rights to a physical infrastructure. While they remain on the scale of the house or the apartment, I think we can construct an analogy to the discussion of Heimat and what Scheffler said about the fifth dimension of it: Heimat or home has a clear emotional dimension. A person must be able to feel it-to feel at home.

This emotional dimension also shows up in the book called The Politics of Home by Dutch sociologist Jan Willem Duyvendank (2011). Duyvendak observed that both

lichen zu wollen. Vielmehr geht es darum festzustellen, welche neuen Bedeutungen das Wort innerhalb der natürlichen und allgemeinen Sehnsucht nach Geborgenheit oder einem irgendwie gearteten Ankerplatz annimmt. 
in Western Europe and the United States 'home' has become more and more associated with nostalgia. In Western Europe people feel confused by the changes within their immediate neighbourhoods that come along with global migration flows. Formerly homogeneous communities have become diversified. As a nostalgic reaction, nationalists use the nation as a metaphor for home, which still tries to tell the story of a homogeneous national society. On the other side of the Atlantic Ocean, the image of a nation as a homogenous society has never been equally powerful. In the United States home resulted from a specific feeling linked to one's own house and family. However, this type of homey feeling is also becoming threatened by global societal changes. The participation of women in the US labour market redefines the role of men and women in relation to the family. Family life is eroding, and US Americans feel 'more-at-home-at-work' (Duyvendak, 2011: 4). Thus, the nostalgia focuses on a past harmonious family life, which is subject to change in post-modern labour markets.

Finally, I would like to stress another point: Heimat is something dynamic. Scheffel (2012) points out that people can develop a feeling of Heimat to very different places in life. This means that we should not necessarily understand Heimat or home as a life-long stable item in a person's lifeworld. In contrast, Gustafson (2001: 681) argues that place attachment can also remain stable over the course of a lifetime: 'It may involve not only the present home place but also [...] earlier places signifying childhood and origin in addition to other meaningful places'. There seem to be places that are more meaningful in a person's life than other places, and these more meaningful places have a higher chance of remaining part of the personal Heimat. Yet, Heimat is subject to change over time, depending on a person's emotional attachment. To conclude, the basic question that results from the Heimat concept is, where does a person currently feel a sense of belonging?

\subsection{Identity and Place ${ }^{13}$}

So far, we have seen that Heimat/home is a difficult-to-grasp concept. Identity and processes of identification are complex social phenomena, too. They are difficult to operationalise. In sociology 'identity' and 'identification' are mostly understood as describing the relationship between an individual and an object of reference. The latter is often understood as a social group. However, in human geography, forms

13 I have presented parts of this section in a conference paper titled 'Identity between places and peers? Insights from a study about multilocal creative knowledge workers in the European Union' during the Annual RC21 Conference 2011 'The struggle to belong. Dealing with diversity in 21st century urban settings', Amsterdam (The Netherlands), 7-9 July 2011 (http://www.rc21.org/conferences/amsterdam2011/prog-19.php; accessed 14 April 2014) 
of 'place-based' identification or place identity are particularly relevant topics. Let's have a look at both disciplinary approaches.

\subsubsection{Identity in Sociology and Psychology}

Identity and identification form a complex issue that takes on a prominent role in psychology and sociology. After several decades of research, the terms could be found in various scientific dictionaries, which reflect a common sense of definitions. Jenkins for example says (2008: 5):

'As a very basic starting point, identity is the human capacity - rooted in language - to know 'who's who' (and hence 'what's what'). This involves knowing who we are, knowing who others are, them knowing who we are, us knowing who they think we are, and so on: a multi-dimensional classification or mapping of the human world and our places in it, as individuals and as members of collectivities. It is a process - identification - not a 'thing'.'

Similarly, Bhushan (2003: 127) remarks:

'Identification refers to a social-psychological process which involves the assimilation and internalization of the values, standards, expectations, or social roles of another person or persons (for example, one's parents) into one's own behaviour and self-conception. [Thus it includes] having a sense of 'oneness' with him, and being able to put one's self imaginatively into his position.'

Hence, identity is the outcome of a process of identification. This process of identification can be understood as the placing of the self in the closer and the wider world. Here, place is not necessarily to be understood as a physical one. Rather it refers to a social place, to a personal understanding of one's own position in the society. As identification is a process, its outcome, identity, is not something static that endures once constructed. Rather, identity changes continuously. Thus, from an analytical point of view, it is more interesting to study processes of identification instead of 'identity', which could not be more than a temporary snapshot. Although an interesting starting point, understanding identification is not that simple and we should have a more detailed look at how it actually works.

Weichhart (1990) provides an interesting overview about the origin of identity research. I will repeat his chronology here, as presented in the second chapter of his book Raumbezogene Identität (1990: 14-24). Weichhart mentions that the study of social identity dates back to the work of psychologist Mead (1934), who studied the development of the 'social self'. Mead was a representative of Symbolic Interactionism, who thought the social self to be a result of processes of social interaction. The most important element of such interaction is verbal communication, through which the individual receives feedback about their appearance as perceived by others. This feedback then becomes internalised into the reflection about and the construction of one's own personal identity. 
Weichhart (1990) then remits to Stone (1962). Stone refined Mead's ideas about the production of identity by distinguishing between 'appearance' and 'discourse'. While Mead assumed that individuals take roles within an interaction, Stone criticised Mead on the grounds that he did not explain role-taking. Stone says it is especially the moment of 'appearance' - immediately before first verbal communication - which helps individuals to understand the other and their role. Only then can 'discourse' emerge - namely the communication about specific content between interacting individuals. Stone distinguishes between two processes which are related to that 'communicative situation' and which lead to the development of identity. First, there is the 'identification of' the interaction partner in the moment at which the interaction starts. This process is based on the 'appearance' of the other. Once having identified the other, a second process of 'identification with' the interaction partner begins, in which the conversation or 'discourse' about an issue leads to a feeling of sameness (or difference). Therefore, Stone's approach to explaining identification consists of a distinction between the cognitive perception of an interaction's environment and the actual content of the social interaction (cf. Weichhart, 1990: 15f.). Later, Stone (2005: 143) summarised: '[...] identity is established as a consequence of two processes, apposition and opposition, a bringing together and setting apart. To situate the person as a social object is to bring him together with other objects so situated, and, at the same time to set him apart from still other objects. [...] To have an identity is to join with some and depart from others, to enter and leave social relations at once.'

According to Weichhart (1990), Graumann (1983) represents a third approach by adding the process of 'being identified' to Stone's two perspectives of 'identification of' and 'identification with'. He assumes that people are not only actively identifying others and deciding about identifying with them, but they are also being identified by others as having certain characteristics. Being identified means to be ascribed social attributes. The pattern of social attributes with which a person becomes ascribed will then be internalised during the process of socialisation. Graumann also broadens Stone's 'identification of'. According to Graumann, it should be labelled 'identifying the environment', which includes the psychological process of experiencing sameness or difference with other objects. For him, this identification consists of categorising the environment and thus being able to orientate within it. Finally, Stone's 'identification with' is modified by Graumann into a 'identifying with one's environment': people identify with persons and things in their environment that are similar to themselves or represent personal aspirations. They work as 'models' or 'reference groups' that shape the appearance of the respective individual (cf. Weichhart, 1990: 16ff.).

Finally, there is also a distinction between 'personal identity' and 'social identity'. Concerning personal identity, Doise (1998: 23) remarks: 'Personal identity can be considered to be a social representation, an organizing principle of individual positioning in a field of symbolic relationships between individuals and groups. [...] Not all social relationships in which we take part are equally present in our minds. Depending on situations, various relationships become salient and give rise to different identity dynamics.' 
Complementary to this concept of 'personal identity', and according to Tajfel's Theory of Social Identity, Mühler \& Opp (2006) understand 'social identification' as a process in which an individual actively tries to be as similar as possible to a social group that this individual evaluates positively. As a consequence, being recognised as part of that reference group by others leads to a positive social identity and individual satisfaction. Social actors thus continuously engage in the amelioration of the social group's perception in the whole society in order to maintain their positive social identity. However, there is a difference between self-ascription and external ascription by others.

We can see that identity as discussed in sociology and psychology is a complex interplay between individual perception of one's own position in a society and the external perception of this position by others. The individual person reflects on what others think of them, and reflection includes a continuous evaluation of reference groups. Furthermore, Graumann has already pointed to the role of physical objects and things as well as the physical environment for processes of identification, which could be considered a bridge to place-based identity.

\subsubsection{Place-Based Identity}

Peter Weichhart (1990), a human geographer, is interested in the cognition of space. He tried to combine geography with sociological and psychological theory in order to understand what role 'place-based identity' might play for an individual as well as for society as a whole. Weichhart (1990) suggests that identification processes could also be based on 'reference places' instead of reference groups/persons. As long as the relevant place has a certain symbolic function and could be defined with a certain character, an individual might also be identified by a relation to such a place (e.g. place of birth, place of residence). Not only the individual level might be subject to place-based identity, but also collective identities could emerge which help to characterise a group of people from a certain territory. Here, the traditional 'us vs. them' divide comes into play: once a certain group of people internalises an ascribed identity, they start to use it to distance themselves from others. For such distinction this group might also start to express claims to a certain territory that they understand as their own.

Since the 1970s, 'place' increasingly showed up as one referential dimension in studies about identification. Here, place is integrated into the process of identification in terms of an individual's or group's cognitive representation about that place (Weichhart, 1990: 20). This cognitive representation helps people to distinguish 'this' place from 'other' places. In this sense, places are thought of as objects of the everyday lifeworld, which then become part of spatial cognition as well as the communication between individuals. They help people to orientate both in a physical (denotative) as well as a psychological (connotative) way. In this sense, places could be used to iden- 
tify a spatial environment according to Graumann's 'identifying the environment' or Stone's 'identification of'.

Yet, also Stone's ‘identifying with' or Graumann's 'identifying with one's environment' and 'being identified' open a second perspective on the role of place in processes of identification (Weichhart, 1990). Here, place is not functional to spatial orientation, but it works by creating a place-based individual or collective identity that allows its users to group others into being 'from here' and 'from there'. Individuals use certain places as part of the social self. On the other hand, they are also ascribed place-related parts of their identity by people from outside this place. Weichhart concludes (1990: 98f.): 'Space-related identity must thus be interpreted as 1. the subjectively perceived identity of specific places and 2. their collectively perceived identity [...] 3. those spatial segments of environment that an individual includes in his/her self-concept [and 4.] the identity of a group that considers a certain segment of space as a partial element of the ideological representation of the 'we-concept' or as defining criterion for the determination of identities of other groups ('they-concept')'.

Place-based identity fulfils several social functions. First, it helps individuals maintain their 'ego-identity'. Individuals use spatial references to find security, to stimulate activity, to interact socially and set symbols, as well as to individuate themselves. Second, spatial identity is used to stabilise social systems by integrating different space-related subsystems into the superordinate level. It thus provides reference and orientation and facilitates social order, communication as well as expectation. Third, it leads to group cohesion and solidarity and thus fosters social integration (Weichhart, 1990: 99f.).

Weichhart describes collective place-based identities as 'symbolic communities', which are characterised by a low emotional involvement of the individual participants, and in which the spatial referent is understood as delimitable. This group binding is a result of a symbolic binding and loyalty to the reference group. It is less an outcome of jointly inhabiting a certain territory. Thus, there is not necessarily real interaction between the group members. Here, also Anderson's concept of 'imagined communities' could help an understanding of place-based identity (Anderson, 1983). The image of a community from a certain territory could cause an individual to feel attachment and belonging. An individual must not have personally met the community's members in order to identify with that community. To identify with this community it is sufficient to know what type of image this community has and if one would like to be identified as a member of that group, too (cf. Phillips, 2002).

Finally, there is the question of the most relevant spatial scale of reference, which Weichhart supposes to be the local and the neighbourhood. He assumes (Weichhart, 1990: 100) 'that the cognitive as well as the self- and 'we/they'-related aspects of placerelated identity are equally orientated on a continuum of scale ranging from personal space to national and supranational entities and that the aspects are focussed on the various scales depending on the specific context of action and situation. Seen from the perspective of the individual, however, the local level turns out to be the principal 
dimension of reference. The experience gained on this level of space-related identity may be transferred to other objects of reference on different scales by means of generalisations based on similarities'.

Most people thus oscillate between different geographic scales when it comes to defining their spatial identities. Yet, the cognitive departure for this oscillation starts mostly at the local level-that which can be experienced in everyday life. This oscillation is organised as a process of transference of local cognitive models to the more abstract supra-local levels. Then, the level of reference is dependent on the specific situation in which an individual is asked for their identity. The immediacy of the local level becomes the most important factor for its predominance in individual place-based identification (Weichhart, 1990: 78). Weichhart argues that the local level is a sphere that can be experienced directly through the corporeal senses (seeing, touching, smelling, hearing, etc.). One can walk through a neighbourhood or a city, but walking through a region might become quite an undertaking. Finally, walking through a country or a continent really takes courage and fitness. Here, Lynch's concept of 'legibility' might play a prominent role, too (Lynch, 1960). Lynch described howplaces have different degrees of legibility, which means that there is a varying simplicity in orientation. This idea also brings us back to the physiological senses, giving the local scale a prominent role. However, when it comes to supra-local scales of identification, external influences also affect the individual perception (e.g. nation building, place branding, etc.). These external images and identities might be internalised by individuals and as such become relevant for personal place-based identity (Mühler \& Opp, 2006).

Mühler \& Opp (2006: 18) operationalise 'regional identification' as a process in which a territorial unit becomes an 'object of attitude' (Einstellungsobjekt) for an individual. A person actually does not identify with a geographic place itself but with a group of people that are characterised as living in, or originating from a place/region. For an individual, these inhabitants' territorial origin gives them a certain characteristic to which the individual might feel emotionally or affectively related. The individual might evaluate these characteristics as positive. Based on this positive evaluation, they might then develop a sentiment of belonging to this group of people. Place-based identification is thus a type of identification in which a social group is the origin of the feeling of attachment. Yet, this feeling is focused on the mediating object of the 'place' or 'region'. It is about identification with a social group whose unifying moment is a 'place' (Mühler \& Opp, 2006: $22^{14}$ ): 'Often [we] speak of a 'regional' or 'supra-regional identification', and here we mean 'identification with a group, which amongst others can be characterized by the belonging to a specific region'.'

14 Translated by the author from the German original: '[Wir] sprechen oft von 'regionaler' bzw. 'überregionaler Identifikation' und meinen 'Identifikation mit Gruppen, die u.a. durch Zugehörigkeit zu einer Region zu charakterisieren sind'.' 
To conclude, place-based identification is composed of two major reference categories: objects and persons. Physical objects (e.g. buildings, landscapes, etc.) work by directly influencing positive or negative associations with a place. Furthermore, people who are identified by others as stemming from a place - or that self-identify with a place - base these place-based parts of their identity also on social components, such as the local community of a place (cf. the concept of 'socio-scapes' as described by Albrow, 1997). A place becomes characterised by the people who inhabit it. Being from there is then only a simplification of the actual connotation of being like the other people from this place. Thus, the social composition of a place translates into its image. Finally, place-based identification is multi-scalar, with the local scale understood as the dominant one.

\subsubsection{Place-Based Identity in the European Union: Some Empirical Insights}

In the European Union, European integration is supposed to have a strong effect on processes of identification among EU inhabitants. Mühler \& Opp (2006) offer the critique that this wide-spread hypothesis is not empirically grounded. They used a panel survey with about 1,000 Saxons to test some common hypotheses and to study the dynamics of their identification between 2000 and 2003. Basically, they assume that different geographic scales might be combined in processes of individual place-based identification, and that their hierarchies might vary over time. They also look for the interdependencies between identification with a region and civic engagement.

Mühler \& Opp use two main indicators to measure place-based identification: 'feeling part of a certain place' and 'being proud of originating from a certain place'. Three hypotheses guide their analysis (2006: 45-49): (1) a higher quality of life increases regional identification; (2) primary socialization (being born and growing up) in a region increases regional identification; and (3) conflict situations, which stress the population of a region, increase regional identification. Furthermore, they suggest that regional identification causes (1) region-oriented behaviour (regional consumption, representation of the region); (2) commitment to regional politics; (3) regional orientation - personal interest in regional developments and societal life, low willingness to move; and (4) regional centrism, which means the degradation of other regions and people from other regions, especially when other geographic scales are missing in the individual identity. These four supposed effects of regional identification are combined in the notion 'regional focussing' (regionale Fokussierung) (Mühler \& Opp, 2006: 49). Mühler \& Opp’s sample was drafted in the Saxon City of Leipzig and in the rural district of the Ore Mountains (Erzgebirge) in Southern Saxony.

The findings of Mühler \& Opp (2006) suggest that identities were quite stable between 2000 and 2003 (about 50\% of respondents did not change their identity patterns). Respondents' identification with Europe rose by $8 \%$ and regional identification with Saxony also grew. Furthermore, their results show that the smaller the geo- 
graphic scale, the stronger place-based identification became. The immediate local environment was the most important geographic scale for place-based identity. This supports Weichhart's assumptions concerning the importance of the local scale in place-based identity (cf. section 3.2.2). In addition, Mühler \& Opp found that there is a significant difference between the urban and the rural sample in terms of identification with the local level: in the rural sample this scale is far more important than in the urban sample. Finally, between 2000 and 2003 identification with Europe was more stable among the urban interviewees (Mühler \& Opp, 2006: 136f.).

In testing for their initial hypotheses, Mühler \& Opp came to interesting results. Concerning their socialisation hypothesis, Mühler \& Opp (2006: 230) found that the place of birth and where a person was raised had no dominant impact on place-based identification. Rather, positive associations (such as the evaluation of regional dialects) during primary socialisation are an important basis of regional identification. The duration for which a person has lived in one place is just as seldom a predictive factor for identification. Rather, regional identification is a continuous learning process. As Mühler \& Opp (2006: 231) put it, regional identification is not something given with birth and childhood, and it could be unlearnt. Furthermore, a 'new' regional identity could be learnt later in life, mainly based on positive experiences with a region and its inhabitants. Unfortunately, the quality of life hypothesis could not be completely verified by Mühler \& Opp. Respondents in their study did not report linkages between their quality of life and increasing regional identification. Third, the conflict hypothesis was verified at least partially by Mühler \& Opp (2006). When it comes to place-based identification, the regional (Saxon) identification was largely influenced by a perceived conflict with, or discrimination from, Western Germans. This perceived discrimination increased regional identification on a sub-national level.

Mühler \& Opp (2006) identified two distinct subgroups of people according to their regional identification. First, there are people who feel that they are part of a regional group that is subject to discrimination by other regions' groups. They base their identification on the shared threat from 'outside', effecting a rather conservative and exclusionary group character. The second subgroup is composed of people who have moved to the region later in life and have 'learned' their regional identification based on their satisfaction with the quality of life in their new environment. This subgroup is rather open-minded and inclusionary. Furthermore, the first subgroup expresses more negative perceptions of EU institutions and policy; the second subgroup is more positive about EU issues.

Mühler \& Opp (2006) also analysed linkages between the different scales of identification. To repeat, general discourse suggests that European integration has a positive impact on the development of a European identity among Europe's inhabitants. Here, reciprocal causality could also be assumed: European integration is legitimised and can take place successfully only if there is a common European identity. Both of these assumptions would have the potential to diminish the relevance of the national and sub-national scale for place-based identification. Mühler \& Opp (2006) criticise 
both these hypotheses as not empirically robust, and they refer to the Theory of Cognitive Balance (kognitive Gleichgewichtstheorie) according to Heider (1958), who stresses a proportional link between the different cognitive elements that are inclusionary along a hierarchy. Mühler \& Opp translate this theory into the scales of identification (a region being a part of the nation, the nation being part of the EU, etc.). Their empirical results show that a stronger national identification is linked to a strong European as well as regional identification. This means that the rise of European identity does not automatically replace national identification; rather, it accompanies and complements national and regional identification.

In addition, Mühler \& Opp suggest that European identification is not only linked to regional and national identification, but also to the positive or negative evaluation of EU institutions and policy. They found individual policy decisions (e.g. the introduction of the Euro as joint currency; Schengen; Eastern European accessions) to be relatively unimportant, whereas EU institutions played a more prominent role in determining identification with the European scale.

Finally, Mühler \& Opp (2006: 231) studied the relationship between Heimatgefühl (personal feelings about home) and regional identification. Their findings suggest that Heimatgefühl is something given by birth and the place where one spent the first years of childhood. This feeling about a place of the 'personal roots' does not change in time and is not subject to any processes of cumulative causation. However, it is not automatically translatable into a feeling of regional identification, which is influenced by other biographical developments later in life.

Thus, we can see that home and regional identification are different things. We should be aware of that and not mix them up when speaking about the ways in which people are rooted in place and space. Yet, both concepts - home/Heimat (section 3.1) and place-based identification (section 3.2) - allow for interesting insights into the origin of the emotional side of belonging to a place, or belonging within a space. The subsequent section 3.3 will now have a look at a concept which more strongly focuses on a social practice, namely that of dwelling in a place.

\subsection{Dwelling and Living in a Place ${ }^{15}$}

The German term Wohnen, for which I will use the English term 'to dwell', is listed in several sociological dictionaries. Herlyn (2003) e.g. describes dwelling as one functio-

15 This section was part of a conference presentation titeled 'Multilokalität und die Bedeutung von Orten: Die Beispielgruppen Großeltern in Nachtrennungsfamilien und kreative Wissensarbeiter/-innen. which I held in collaboration with my colleague Giulia Montanari during the Dortmunder Konferenz 2012 'Mobilitäten und Immobilitäten' in Dortmund, 10 February 2012. The results were published in Nadler \& Montanari (2013). 
nal element of cities. According to Herlyn the basis for being able to dwell is an apartment or a house, which is characterised by the fact that a person or a group of persons exert their exclusive right of disposal over this physical space. Inhabiting an apartment or house, which we can also call 'dwelling', is organised in a specific logic that allows for a strict differentiation between private life and the various public spheres of life (e.g. work, hobbies, associations, and neighbourhood). The locational decision of where to dwell has consequences for many other aspects of one's lifeworld. Neighbourhoods have different images and these can translate into neighbourhood effects and are differently equipped with infrastructures that define opportunities for living one's own life. Furthermore, the neighbourhood in which a person dwells also marks how much a person lives in it. Herlyn remarks (2003: 377 ${ }^{16}$ ): 'Generally speaking, the social relations within a neighbourhood can be considered a hinge through which the distanced contacts within the smaller group are linked. Although the neighbourhood in the modern city has lost many functions for adult inhabitants, and against the social distance which is characteristic for city life, there are still various relationships that are rooted in the neighbourhood. Children and elderly people rely on neighbourhood relationships which remain important functional elements in their everyday life. Yet, one can observe that inhabitants of large cities live in a way which is more oriented towards family than towards the neighbourhood.'

Häußermann \& Siebel (1996) understand dwelling as one partial aspect of a person's 'conduct of life' (Lebensvollzug). According to Elias' idea of the life style, Häußermann \& Siebel speak of a 'dwelling style', which is characterised by four distinct functional elements (1996: 15): first, dwelling refers to all activities that are not part of the work life. Thus, dwelling refers to private life. Second, the household that dwells together is considered a social unit, commonly called a family. Thus, the dwelling itself is the private place of the family. Third, a dwelling has a socio-psychological dimension. The dwelling is the place where a person is alone in absolute privacy and intimacy. Activities that are subject to shame take place here. Fourth, dwelling is regulated on a societal level through norms and institutions. Apartments and houses are traded on a market. Finally, Häußermann \& Siebel also acknowledge that dwelling understood as both an act and as the house/apartment - has a symbolic value. How and where a person dwells signals social status and can result in social distinction (1996: 44).

16 Translated by the author from the German text: 'Allgemein sind die gesellschaftlichen Beziehungen im Stadtteil als Scharnier zu verstehen, durch das sich die distanzierten Kontakte in der kleinen Gruppe verbinden. Wenn auch in der modernen Stadt die Nachbarschaft für die Erwachsenen weitgehend entfunktionalisiert ist, gibt es doch noch trotz aller stadttypischen sozialen Distanz zahlreiche nachbarschaftliche Kontakte, die v.a. für Kinder und alte Menschen wichtige Funktionen im alläglichen Leben übernehmen können. Trotzdem gilt: Der Großstädter wohnt weniger nachbarschaftlichorientiert als vielmehr familienorientiert.' 
Stracke-Mertes (2003: 156) also understands dwelling as one of the human's basic needs. This need to dwell can be satisfied by one's own apartment or house that allows for complete self-determination concerning social proximity or distance. It represents a retreat from social control. The dwelling is the space/place where a person controls their own territory. Apart from exceptions, no other person can interfere in this territory. Within the limits of social norms and rules, a person can do whatever they want within their 'own four walls'. This territory is protected from the outside world and is therefore strongly related to the personal identity. Within the dwelling a person is relieved from social roles and can become themself again. Goffman (1959: 106ff.) thus understands the dwelling as a 'back region' which allows people to relax from the social roles that they have to play in the public sphere. Social norms are only valid in a limited way.

Furthermore, in action space theory, the dwelling is considered 'the most important pocket of local order', around which a person organises their everyday life (Ellegård \& Vilhelmson, 2004: 284ff.; Kramer, 2012: 90). Yet, in the light of increasing global mobility, dwelling as a social practice is changing quickly. One outcome of this change is that people and families dwell in different places at the same time. This means that the aforementioned characteristics of dwelling become threatened by new empirical models. Weiske et al. (2009) deal with that issue in their study on multilocal households. Thus, they add to the discussion that dwelling cannot be understood anymore as one household living in one apartment. Dwelling can still mean one household, but this household may refer to several apartments that are used in everyday life.

This idea of Weiske et al. (2009) leads to difficulties in understanding the social practice of dwelling. According to more traditional views (cf. above Häußermann \& Siebel, 1996) dwelling was a social practice that helped the individual person draw a neat line between the public/professional and the private spheres of everyday life in one place. Now people are starting to have two or more such dwelling places. What does this mean? Scholars who deal with the study of such multilocal practices of dwelling acknowledge that dwelling then cannot be thought of as such a concentration of social functions in one specific locale. The social functions (distinction private/public sphere, social back stage, intimacy, etc.) are distributed to different locales, but administrative systems are not prepared for this. For example, people are still registered mainly in one place, have one specific address, and pay taxes in one specific place. Therefore, Hilti (2009) suggests understanding 'dwelling' not according to an allencompassing concentration of life spheres around one place. She prefers to focus on the dwelling's main function: it provides a place to 'stay overnight'. If someone stays overnight, then this person dwells.

Likewise, Stock (2009) observes that 'dwelling' is more difficult to define in a mobile and multilocal world. According to Stock, dwelling can be described as the social practice of 'dealing with a spatial environment' (sich mit seiner räumlichen Umgebung auseinandersetzen; Stock, 2009: 108). This practice happens all the time 
and everywhere. Dwelling thus is independent of one's own apartment and of registered residency. It also becomes independent of 'familiar' and of 'foreign' places (Eigenbzw. Fremdorte). Stock's reflection reveals that dwelling today has to be thought of differently than some decades ago. It is no longer about defining the centre of the private sphere of life in exactly one place from which a person starts every day into the public outside world. However, I believe that both approaches also highlight the difficulties of redefining dwelling in the mobile world.

Schier (2009) tries to shift analytical attention from a place to the family. She suggests looking at family interaction in everyday life instead of studying apartments and neighbourhoods. This includes the idea that people 'dwell' within the compound of their family. Then multilocal dwelling becomes analytically approachable again, and the multiplicity of places does not disturb the operationalisation for empirical studies.

These different approaches to defining 'dwelling' show that this social practice, which is heavily related to place, is changing quickly. It still remains a central issue for understanding how people are 'rooted' in space. Even though it is changing its character, dwelling remains the private basis for the public social life. It remains the 'back region', as Goffman (1959) called it. The clear borderline between private and public places, which was formerly marked by the apartment door, seems to have blurred. With more places becoming part of 'dwelling' as social practices, it can be assumed that semi-public dwellings are emerging. So far, first attempts to conceptualise 'dwelling' in a mobile world have remained unsatisfying. Making the definition of dwelling less precise runs the risk of making it a catch-all notion. At the same time, sticking too much on all functional elements of dwelling in one single place is not the only reality anymore. A new way of understanding dwelling is necessary to understand how people relate to place, and how they accentuate belonging by dwelling somewhere.

\subsection{Jung's Concept of Psycho-Social Sedentariness}

Recently, Matthias Jung presented another interesting approach to study the rootedness of multilocal people. Jung (2013) developed a model that he calls 'psychosocial sedentariness' (psycho-soziale Seßhaftigkeit). From an everyday perspective, the central property of 'sedentariness' is the monolocality in one specific geographic place. Jung, however, mentions that sedentariness also includes other aspects that are not necessarily bound to geographic location. His model is based on the observation that there are three main aspects of sedentariness. First, people are corporeally sedentary. A person has to acknowledge that they are positioned in their body and will experience their own lifeworld through this incorporation. If a person does not accept their own body, they cannot become sedentary in any other way. Second, a person is psychologically sedentary. One's own life plan and own practice has to be 
part of an individual's relation to themself. This means a person must develop a personal identity and a consciousness about themself. Here it is important that a person is capable of anticipating their own future, making plans, and developing strategies for their own life. And third, a person is socially sedentary insofar as they are part of different forms of social community. This includes different levels from the family to the wider society.

For an individual's sedentariness, a fundamental issue is that these three aspects are all characterised by congruence between a person's individual perception and the objective situation in which they find themselves in a given moment in life. These three aspects are not necessarily related to physical space. Jung uses the example of scientists or artists to illustrate how sedentariness can have a rather abstract and nonphysical character (2013: 43 $\left.{ }^{17}\right)$ :

\footnotetext{
'People who exhibit professions which are oriented to self-actualization and in which they are not only bearers of partial social roles, but in which they are involved with their personality as a whole, as a total individual, are typically sedentary in an abstract way, namely in a thing. This type of sedentariness must not necessarily be bound to a specific locality as long as a minimum level of favourable conditions allow for dedication to this thing. Contrary to those who understand their job merely as a means of earning money, people who understand their appointment in an emphatic way and who work in artistic and scientific professions as well as religious virtuosoship are exemplary for this sedentariness.'
}

This includes the methodological difficulty that one cannot directly record this abstract psycho-social sedentariness. It has to be reconstructed, using case contrasting, from biographical narratives, as Jung indicates.

Leaving aside corporeal sedentariness, Jung then examines how the two forms of psychological and social sedentariness were constituted in different moments in history. He starts his reflection with the pre-modern and traditionalist cultures. Here, a person was basically pre-defined by birth. A person was born into a position in the social system of the place where they lived, and this social position was regulated by norms. It included a given set of rights and obligations. A person did not have much flexibility in defining their own position if they wanted to be accepted by the community. Other than a social role, which one could leave without being sanctioned, a negotiation about one's social position often led to one's expulsion from the community. People were not allowed to develop individual life plans; rather, life was planned

17 Translated by the author from the German text: 'Personen, die in Verwirklichung ihres Lebensentwurfes Tätigkeiten ausüben, in die man nicht nur als Träger partialer Rollen, sondern als ganze Person, als Individuum in seiner Totalität, involviert ist, sind typischerweise abstrakt sesshaft in einer Sache, ohne dass diese Sesshaftigkeit einer bestimmten Örtlichkeit verpflichtet sein muss, solange nur günstige Bedingungen dafür gewährleistet sind, sich dieser Sache widmen zu können. Dazu zählen beispielsweise der in einem emphatischen Sinne, das heisst im Unterschied zu blossem Erwerb verstandene Beruf, das künstlerische und das wissenschaftliche Handeln oder auch das religiöse Virtuosentum.' 
for them, as Jung remarks. The only freedom that a person had was to build a secret opinion about this social position. Yet, the way one acted had to be in line with the ascribed position. In this pre-modern culture, psycho-social and geographic sedentariness were congruent.

Second, Jung examines the sedentariness in nomadic communities, which are built around a culture of mobility. Jung observes that European scholars often have difficulties considering nomadic communities to be sedentary ones. Nomadic life is associated with immediacy, asocial behaviour and a lack of plans for the future. Jung, however, mentions that nomadic people are psycho-socially sedentary even though they are not settled in a stable place. Nomads incorporate the cognitive modes, behaviour, rites, symbols and communication styles of a mobile community. They are sedentary in mobility. Jung says that this is the differentiating criterion of people who move a lot, such as in contemporary US American society. Those who move a lot in the USA remain psycho-socially sedentary and immobile; they are only physically mobile. The nomads are both psycho-socially and physically sedentary within mobility. Empirical evidence for the difference between physical and psycho-social sedentariness is given by the problems that occur if nomads are forced to settle somewhere by national governments; they then remain psycho-socially mobile, even while they are physically constrained to immobility.

Third, Jung looks at the sedentariness of those people who today are termed 'nonsedentary'. Their situation is rather precarious in terms of their psycho-social sedentariness. They perceive and understand their current life situation as a temporary passage, which is a transition to a more stable and normal life. Thus, they have not developed a psycho-social sedentariness in their current life. This goes along with a difficulty in developing realistic plans for the future that will lead to a better match between individual perception and objective situation.

Jung, studying long-term unemployed people and their psychological situation, found that in particular one's own parents and family of origin, as well as current social contacts, are of importance in order to develop one's own psycho-social sedentariness. One's own family provides the basis for developing an independent life, which is then reflected in one's social contacts. Examining his cases, Jung found that people often have only a few anchor points in life that help to establish psycho-social sedentariness. If these anchor points are highly unique and not substitutable, and if people do not exert power over their existence, they might end up in psycho-socially precarious situations. Different psycho-social sedentariness patterns can thus cause situations that are more or less advantageous for a future independent life.

What Jung offers with this approach is a way of understanding the rootedness of people, which is not directly geographical or based on physical space. Even though it is only an initial draft, Jung describes a way of understanding a more abstract type of belonging 'somewhere' and of belonging particularly to one’s own life. 


\subsection{Mobility and its Effects on Roots}

In the literature, there are different positions on what increasing global mobility might do to all these forms of roots that we have discussed so far. Duyvendak (2011) - in his book The Politics of Home - investigates the ways that increasing global mobility affects local feelings of belonging and home. Duyvendak provides a comprehensive review of the current discussion, which links mobility and rootedness to place. Many scholars tend to think of people as becoming placeless and uprooted. For example, Morley \& Robins (1995: 121; cited in Duyvendak, 2011: 7) think that mobility 'is provoking a new experience of orientation and disorientation, new senses of placed and placeless identity'. Rapport \& Dawson (1998: 5f.; cited in Duyvendak, 2011: 7) add that 'movement has become fundamental to modern identity, and an experience of non-place (beyond "territory" and "society") an essential component of everyday life'. Both statements indicate that mobility alters the way people are rooted in space or to places. But how does this actually happen?

Table 3.1: Strategies to feel at home in a mobile world; Source: Duyvendak (2011: 12 \& 15); Own redesign: Merge of Duyvendank's Tables 1.1 and 1.2

\begin{tabular}{|c|c|c|}
\hline & Mobility seen negatively & Mobility seen positively \\
\hline $\begin{array}{l}\text { Universalist } \\
\text { position: } \\
\text { generic places }\end{array}$ & $\begin{array}{l}\text { Threat: no attachment to particular } \\
\text { places possible; } \\
\text { People lost in space: no strategies for } \\
\text { home-making available }\end{array}$ & $\begin{array}{l}\text { Opportunity: no attachment to particu- } \\
\text { lar places necessary; } \\
\text { Chronically mobile people: the hotel } \\
\text { chain strategy for home-making; } \\
\text { Looking for generic places }\end{array}$ \\
\hline $\begin{array}{l}\text { Particularist } \\
\text { position: } \\
\text { particular places }\end{array}$ & $\begin{array}{l}\text { Threat: strong attachment to particular } \\
\text { places necessary; } \\
\text { Defensive localists: my house is my } \\
\text { home strategy; } \\
\text { Defending their safe haven against } \\
\text { invasion }\end{array}$ & $\begin{array}{l}\text { Opportunity: strong attachment to } \\
\text { particular places possible; } \\
\text { Elective belongers: the mobile home } \\
\text { strategy; } \\
\text { Avoidance of generic places }\end{array}$ \\
\hline
\end{tabular}

Duyvendak reports two main ideas. First, there are those scholars who argue for a declining relevance of place to the personal feeling of belonging and attachment. Second, there are arguments for a growing relevance of place in a mobile world. Both positions then include differing visions concerning the character of places in the future. Finally, they also differ in the way they think of mobility itself. Mobility can be seen as something positive or as something negative.

Table 3.1 shows the different positions that Duyvendak identified in the literature. Generally, the 'universalists' think that places lose their particularity under the influence of global mobility. The particular meanings of individual places become relativised. People increasingly have social relations with people in other distant places, 
and thus their everyday practices become partly disembedded from single places. Famous scholars such as Castells or Heidegger observed that mobile people become more and more 'homeless' and 'detached' from places and end up in 'spaces of flows' (Duyvendak, 2011: 8f.). Notions such as the 'homeless mind' by Berger et al. (1973) or the 'general condition of homelessness' by Said (1979) point out that mobility used to be perceived as a threat to traditional feelings of belonging in a stable home place. Others such as Braidotti (1994) praised the 'postmodern nomadism'. Despite their different evaluations of mobility, universalists agree on the fact that places might lose their particularity (cf. Duyvendak, 2011). The upper left field in the matrix (Tab.3.1) describes the universalists' position, which considers rising mobility to be a threat to people's feeling of attachment and belonging. For universalists, people will become lost in space and they do not possess strategies for efficient home-making in a mobile world. The upper right field in the matrix represents a more positive evaluation of the increasing mobility. Here, the suggestion is that a group of chronically mobile people consider mobility an opportunity. They look for generic places with a standardised design all over the world; these allow for a feeling of home independent of geographic location. Duyvendak calls this pattern the 'hotel chain strategy' of establishing roots in space. These chronically mobile people do not need particular places anymore because they feel at ease in standardised places.

On the other hand, mobility might also re-root people to their places in new forms, such as e.g. 'glocal' arrangements. Duyvendak calls this the particularist position. Again we can find two different evaluations of rising mobility. Those particularists who stand for a negative evaluation of mobility suggest that a strong attachment to particular places is necessary for people to feel at home. Therefore, mobility is considered a threat. This assumption is based on the fact that there are a large number of people who do not themselves move, but see their beloved home place being changed by incoming mobile people (e.g. international immigrants). They oppose global mobility through defensive and localist strategies (cf. Tab.3.1 lower field left). By contrast, those particularists who think of mobility as a positive thing stress that the increasing mobility allows for more flexible home-making practices. Mobile people have the chance to choose the one place that they like the most from a set of different places. An alternative strategy could consist in becoming mobile and taking one's own belongings on the road (Duyvendank's 'mobile home strategy'; Tab.3.1 lower field on the right). These people mainly avoid generic places and look for and switch between authentic places.

Another important contribution concerning the link between mobility and place stems from an international group of mobility scholars who have developed the concept of 'spatial partnerships' (Raumpartnerschaften) (Dienel et al., 2004). Dienel (2004; 2009) describes that the starting point for their work was the observation that people are becoming more mobile and more multilocal in particular. This means that people increasingly feel attached to several places at the same time, including feelings of being at home and linking one's own identity to several places. A second 
observation was that there are certain systems of multilocal linkages. Specific places are connected more than others because a large group of people circulate between exactly these two places. Third, the authors observed a significant difference in the character of places that are connected with each other. The authors speak of 'contrasting places' (Kontrasträume). The main pattern which Dienel et al. (2004) studied is the link between large cities and rural areas with nice and attractive landscapes. As a result of significant amounts of commuters and second home owners, these places become mutually orientated towards each other (aufeinander bezogen), and they have a certain complementary character which is evaluated positively by the multilocal people. These places thus enter into a 'spatial partnership' (Raumpartnerschaft). As empirical examples, Dienel (2009) mentions Berlin and the Baltic Island of Usedom, Hamburg and the North Sea Island of Sylt as well as Zurich and the Engadin Mountains. Dienel et al. (2004) suggest that such multilocality-based connections between places signify a 'new proximity' (neue Nähe) between formerly distant and unrelated places.

Dienel (2004) explicates that the condition for Raumpartnerschaften is a minimum of repetition of movements between places, which leads to a different perception of places, e.g. different from tourists who are 'first-time-arrivals' to a place. Multilocal and mobile people who create Raumpartnerschaften through their circulation use places in the frame of their everyday life. They do not arrive for the first time to a new place. Thus, they become interested in the places to a greater and less superficial extent than tourists normally do. The link that individual multilocal people create between places is called 'informal spatial partnership' (Dienel, 2004: 21, 29ff.). Against this type of Raumpartnerschaft there is also a more collective type of 'institutional spatial partnership', which emerges when political and social actors have become aware of these relations between two places. These types of institutional spatial partnerships are based on individual informal ones, and thus on the concrete socio-spatial practice of a significant mass of individuals. They could be imagined as a type of twin city partnerships, but between contrasting places such as smaller villages and large cities.

Raumpartnerschaften allow for social innovation because individual multilocal people seem to behave distinctly in their different places. This means that in one place they would do what they would or could not do in the other place. They experiment with different modes of behaviour which can be transferred between places. Dienel also offers a possible explanation for such place-differentiated behaviour (2004: 24 ${ }^{18}$ ):

18 Translated by the author from the German text: ,Historisch-soziologische und anthropologische Deutungen stimmen heute weitgehend darin überein, dass hinter dem Verhalten des modernen Freizeitreisens die Suche der Reisenden nach komplementären Lebenserfahrungen außerhalb ihrer Alltags- und Arbeitsroutine verborgen ist: Das räumlich-komplementäre Bewegungs- und Aufenthaltsverhalten ist Ausdruck für den Wunsch nach komplementären Verhaltens- und Erlebnismöglichkeiten.' 
'Historio-sociological and anthropological interpretations today mainly agree on the fact that the search for complementary experiences, outside of routinised everyday work life, is the main driver for modern leisure travel: the spatially complementary travel and soujourn behaviour is an expression for the longing for complementary possibilities to behave and experience.'

Dienel thinks of multilocality as an escape from the perceptional constraints related to life in the industrialised cities. Multilocality is not an escape from one place to another because of material deprivation in the original place. Rather it should be understood as the search for a different experience of time-space, which cannot be offered by contemporary city life. Thus, people look for contrasting and complementary experience.

Related to the contrasting character of places, people also act in a contrasting/ complementary way in these different places. Dienel remarks (2004: 26 $\left.{ }^{19}\right)$ : 'The notion of 'contrasting place behaviour' on the one hand represents the need for the experience of spatial contrast (e.g. between the place of residence and the place of vacation), on the other hand it expresses the wish to act out one's own scope of experience in social terms, namely to live different social roles, characters and lifestyles within one life.'

Thus, mobile people want to combine distinct, spatially rooted 'sub-lifeworlds' within their total lifeworld. The individual person perceives their own informal Raumpartnerschaft first of all through a mental and cultural perspective. According to Dienel (2004; 2009), most mobility studies focus on transport, the exchange of goods and materials or even information, but the study of Raumpartnerschaften calls for a focus on space perception and individual biography. Even if the involved places might be the same for two different persons, the meaning of these places to these persons will vary strongly, and this variation is not only based on standard socioeconomic variables such as gender, class, age, income or education. It is also strongly influenced by personal history, socialisation and cultural background. In addition, the immediate spatial environment in which people act in their places is of upmost importance for their perception. Thus, a focus on the local scale is important. Dienel lists several variables that might be helpful for studying informal Raumpartnerschaften on the level of individuals (2004: 27): the place of origin, the place of childhood/ growing up, the mobility of parents during the own childhood, the own places after childhood, living places, reflections about home, the origin of the partner, children and their spatial relevance, and individual interests in the professional and the leisure sphere. Thus, contrast originates from the very individual perception of it, which is

19 Translated by the author from the German text: 'Der Begriff "Kontrastraumverhalten" steht zum einen für das Bedürfnis, räumliche Kontraste (z.B. zwischen Wohn- und Urlaubsort) zu erfahren, zum anderen für den Wunsch, einen räumlichen Erfahrungsspielraum auszuleben, mehrere Rollen, Existenzen und Lebensstile innerhalb eines Lebens zu verwirklichen.' 
rooted in individual biography. At the same time it also has an intersubjective as well as an objective character.

In particular, travel itself between places is an important aspect of understanding how people perceive informal Raumpartnerschaften. Dienel describes travel as follows (2004: $\left.27^{20}\right)$ : 'Travelling to the contrasting place is a switch into another lifestyle and accordingly into the other character. [...] The physical movement towards the contrasting place equals stripping off the character of the recently left other place. Travel can be a means to an end, for the shift into the contrasting place, but it can also be an end in itself.'

Once an individual traveller has a specific interest in the trip itself, travelling becomes an end in itself, allowing for specific emotions and psychic states. If travelling takes place on regular routes and combines the same places over longer periods, then people engage in what Dienel calls 'raumpartnerschaftliches Verhalten' - a specific type of behaviour in the context of individual spatial partnerships, in which travel plays an important role (2004: 27).

Dienel also examines the notion of space through the distinction of two factors influencing its character. First, there are Gestalt factors that define how people perceive these places or spaces. These are mainly defined through landscape and elements in landscapes. Landscapes can both be natural (hills, lakes) or artificial (architecture, built environment in the city). They define the Gestalt of a place and of space. On the other hand there are Flux factors that are related to travel/movement/mobility. These factors consist of specific lines, on which one can move, e.g. roads, train connections, subways in cities, rivers or even airports. They are related to transit and transit spaces. Kontrasträume (contrasting places) normally show varying patterns of equilibrium between Gestalt and Flux factors. Furthermore, Dienel says a spatial partnership (Raumpartnerschaft) involves (2004: 2921) 'the interdependent relatedness of action and the mutual influence to repeated joint acting with a long-term character and which includes a certain spectrum of common aims, patterns of behaviour and projects.'

This means that Dienel understands Raumpartnerschaft as the relations that exist between actors in different places, not between the places themselves. These relations between actors are specific and binding (verbindlich) for they constrain other alternative ways of acting. As Raumpartnerschaften could also be informal, in the form of lived practice by individuals, they consist not only of actors who are related

\footnotetext{
20 Translated by the author from the German text: 'Der Weg in den Kontrastraum ist der Wechsel hinüber in den anderen Lebensstil bzw. die andere Existenz. [...] Die Bewegung zum Kontrastraum ist das Abstreifen der zurück bleibenden Existenz. Sie kann Mittel zum Zweck, zum Wechsel in den Kontrastraum sein, sie kann aber auch Selbstzweck sein.'

21 Translated by the author from the German text: 'Wechselseitige Bezogenheit des Handelns und auf gegenseitigen Einfluß, auf wiederholtes gemeinsames Tun, das auf längere Sicht angelegt ist und ein bestimmtes Spektrum an gemeinsamen Zielsetzungen, Handlungsmustern und Projekten umfasst.'
} 
to each other but also of identities and parts of the lifeworld. Here Dienel uses the notion of multiple place-based identity (multiple Ortsidentität). He says (2004: 30f. ${ }^{22}$ ): 'The individual person not only has one place, with which they identify so strongly that this place could be considered belonging to them, and the person belonging to this one place respectively. These individuals have two or even more places to which they feel to belong. [...] These places become partners by the means of the individual who identifies with different places.'

In both forms, the informal and the institutional Raumpartnerschaft, the partnership relation can have varying degrees of intensity. For informal Raumpartnerschaften, Dienel mentions that a possible empirical differentiation might be based on the frequency and duration of visits to a place, on the character of dwelling in these places, on the financial resources used for living in each place, or on the geographic distance between involved places. Yet, also places that are seldom visited, or even not at all (anymore) might be of relevance if they have a strong emotional impact on the individual. These places might be those that are referred to as Heimat or where a person had lived in the past. Dienel speaks of 'reference places' (Referenzgebiete) here. Finally, differences might also occur in 'how' people look for contrasts and complementarity between places. So far, only few insights exist about the dimensions that make up contrast/complementarity (cf. Dienel, 2004; Dienel, 2009).

\subsection{Synthesis: Roots}

In this chapter I have asked how we can understand the ways in which people relate to places and how they develop a sense of belonging. First, I have presented the German notion of Heimat, which I translated - bearing in mind all difficulties - into the English term 'home'. Heimat and home are terms that are often used as everyday vocabulary by most people when they are asked for their geographic belonging. I showed in section 3.1 that Heimat contains more than the reference to a small cut-out of the geographic world. Further important aspects are the social relations, personal history and emotions associated with a place. The literature on Heimat also suggests that these aspects will no longer all fall together in one specific place as mobility becomes an important part of the individual lifeworld.

I have also presented the origin of the term 'place-based identity'. This concept uses places and people simultaneously to explain the foundations of geographic

22 Translated by the author from the German text: 'Das Individuum hat dann nicht nur einen Ort, mit dem es sich so sehr identifiziert, dass dieser Ort als zu ihm gehörig angesehen wird bzw. umgekehrt das Individuum zu diesem Ort, sondern es hat zwei oder noch mehr Räume, mit denen es sich eins fühlt. [...] Über den Einzelnen, der sich mit den betroffenen unterschiedlichen Räumen identifiziert, werden diese Orte zu Partnern.' 
roots. The images of places, which are composed of both physical and social elements, are main references for place-based identities. Once a person creates roots through an identification with a place, they have positively perceived the place itself as well as the people living in it. As the perception of a place is an important issue here, the local scale was said to be the most important scale for the creation of placebased identity, even though other scales always interfere in processes of identification. However, larger scales (such as regions, nation-states or the European Union) are more abstract and cannot be perceived with one's own senses (walking, seeing, smelling, touching, hearing, etc.). Thus they become less relevant for identification and a feeling of belonging is more easily felt on a local scale (e.g. a city, a neighbourhood, a village and its inhabitants).

This observation has brought us to the notion of Wohnen/dwelling, which in sociology is understood as a social practice of drawing a neat line between the private and the public spheres of one's own life. In particular, the apartment, seen as the materialisation of one's own personality, represents an important physical aspect of a person's belonging in geographic terms. Yet, mobile people today seem to face difficulties in expressing where they are actually dwelling. This difficulty is observed by sociologists who are trying to revise modern conceptualisations of 'dwelling'. As in the notion of Heimat/home, the properties of 'dwelling' as a practice as well as 'the dwelling' as a place do not necessarily merge in the same geographic location anymore. Dwelling often happens across different places. However, social scientists still cannot answer sufficiently how this takes place.

Finally, I have presented a recent approach to understanding rootedness through the notion of 'sedentariness'. Sedentariness is used in everyday vocabulary as a synonym for rootedness. The social scientist Matthias Jung, however, breaks it down to physical and psycho-social components. For Jung, the sedentariness can be described as congruence between the self-perception and the objective situation of a person concerning three aspects: the corporeal sedentariness within one's own body, the psychological sedentariness within one's own personality, and the social sedentariness within different scales of community ranging from the family to the wider society. If the individual perception and the objective situation are not congruent, a person might lack a feeling of belonging. Furthermore, we have witnessed in Jung's ideas that sedentariness additionally consists of physical (geographic) sedentariness, which Jung equates with immobility. If mobility rises, the traditional superposition of physical and psycho-social elements of sedentariness becomes questionable. On the other hand, Jung refers to nomadic societies in order to underline that physical sedentariness might also be equated with mobility. Nomadic tribes can indeed be considered sedentary, namely sedentary in mobility, in a culture of mobility. The question is now which patterns of sedentariness will arise in a postmodern society characterised by increasing mobility. Will we also become rooted in a culture of mobility, and what does this imply?

The $2 \times 2$ matrix of Duyvendak, which I presented in section 3.5, suggests one possible answer to this question. Here, the changing nature of places (the division between 
generic and particular places) and the evaluation of mobility (positive versus negative) are the distinctive variables for the creation of 'belonging' in a mobile world. Duyvendak's approach describes the diversification of people's home-making strategies. Some will appreciate the opportunities to find new types of 'homes' that come along with mobility (such as mobile homes, or generic and substitutable places); others will emphasise the threats. The latter will increasingly have problems feeling at ease in their changing environments (e.g. threatened by 'invading' migrants) or they will feel 'lost in space' when their particular places become generic ones. As a second example, I introduced Dienel's idea of spatial partnerships. Dienel's suggestion is that mobility is not randomly affecting all geographic areas and all people. There will be some people who circulate in regular forms between selected places. The regularity of this mobility will then lead to individual and institutional links between these places, which he calls spatial partnerships (Raumpartnerschaft). These spatial partnerships will have effects on individual feelings of belonging; they provide a context for multiple and hybrid forms of place-based identity, including different places within one person's lifeworld.

To conclude, rootedness in places/space shows up as a mixture of physical and social environments in all of these concepts. Both the physical place and the social interaction/contacts a person has within this place form the decisive fundament of belonging and rootedness in space. Whereas in both traditional and modern societies the physical and the social elements of belonging were mostly located in the same place, this superposition seems increasingly to vanish in recent times. This process is paralleled by a growing diversification of forms of belonging. Formerly collective identities become more and more individualised. In everyday life, traditional terms such as Heimat/home and identity become loaded with various individual connotations. Thus, it is becoming more difficult to study them. Scholars are trying to adapt the common concepts of belonging and rootedness to this new empirical reality. Yet, these adaptations are only at an initial stage, and so far empirical tests have remained explorative or insufficient. 